\title{
EFFECT OF GIBBERELLIC ACID ON SEED GERMINATION PERCENTAGE AND GROWTH PERFORMANCE OF TWO CASSIA SPECIES
}

\author{
A.F. Al-Ma'athedi and Eman H. Mohammad \\ Department of Horticulture and Landscape, College of Agriculture and Forestry, University of \\ Mosul, Mosul, Iraq
}

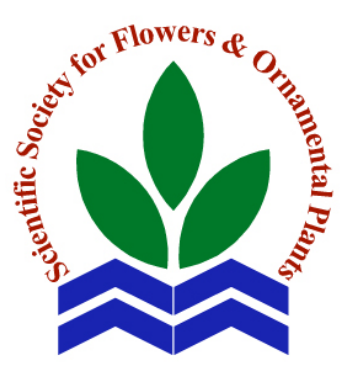

Scientific J. Flowers \& Ornamental Plants, 6(2):99-104(2019).

Received: 9/5/2019

Accepted: 26/5/2019

ABSTRACT: The experiment was conducted in the plastic-house of the Department of Horticulture and Landscape at the College of Agriculture and Forestry, University of Mosul, Iraq during the period of 10/4/2018 and 31/1/2019 on two species of Cassia. Seeds were planted each seed depth twice the length of the seed in a plastic bowl ( $8 \mathrm{~cm}$ height, $6 \mathrm{~cm}$ diameter) full with a medium consisting of perlite, peat moss and sand with $1: 1: 1(\mathrm{v} / \mathrm{v} / \mathrm{v})$ ratio. The developing seedling were then transferred to plastic pots with a diameter of $15 \mathrm{~cm}$ and a height of $12 \mathrm{~cm}$ in the same agricultural medium and transplanted into the plastic house after germination. The experiment was carried out by using two factors in split-plot design within randomized complete block design (RCBD). The first factor was two species of Cassia: Cassia surattenesis and Cassia siamea, while the second factor was soaking seeds in gibberellic acid at three levels of $(0,500$ and $1000 \mathrm{mg}$ $\mathrm{L}^{-1}$ ) for $48 \mathrm{hrs}$. The results showed that $C$. surattensis was superior in all seedling traits except for the leaf area, which was higher than $C$. siamea. Gibberellic acid had an important role in improving seedling properties and when used at $\left(1000 \mathrm{mg} \mathrm{L}^{-1}\right)$ on C. siamea the seedling height and leaf area were increased. There were no significant differences in both species of Cassia in some traits including seedling height. C. surattensis was characterized by its ability to flower in November after the appearance of flower buds at the beginning of the same month. Species differed in their tolerance to environmental conditions $C$. surattensis survived under cold waves, however, $C$. siamea was unable to survive under the same conditions in January.

Key words: Cassia surattenesis, Cassia siamea, GA3, gibberellic acid, germination, seedling growth.

\section{INTRODUCTION}

Cassia is one of the 25 largest species in the world belonging to the Family Leguminosae and the genus Cassia has the most flowering species of economic importance (Sanyal, 2015). Most species of Cassia are grown on a wide scale, they are very useful as trees and suitable in nonfertile lands lacking organic matter and which have the potential to reduce soil erosion and increase their fertility (Khan, 2013). The economic importance of species Cassia surattensis is due to its multiple uses, as it is used for food. The leaf is used for healing cough, sore throat, also for its landscape importance as decorative plants and shade trees or windbreaker. It is an evergreen flowering tree, medium to large in size, fast-growing, loving the direct sun and blooming heavily yellow flowers in the dry season from August to October (Viegas Jr et 


\section{A.F. Al-Ma'athedi and Eman H. Mohammad}

al., 2004; Kumar, 2015; Sanyal, 2015 and Hanelt et al., 2001). The original home of Cassia siamea is Southeast Asia in India and is called yellow Cassia, which gives yellow flowers. It is a medium-lasting tree with large yellow floral clusters and grow in high temperate and warm atmosphere as an ornamental tree (Parrotta and Francis, 1990 and Sanyal, 2015). Cassia siamea used in the formation of plant fences, windbreaks in arid lands, as green zone grown on both sides of the roads and it is important to adopt because of the speed of its growth and sustainability of greenery (Meena and Sharma, 2014; Jonsson et al., 1988 and Sastry et al., 2003).

The dormancy of seeds is one of the most important factors in the propagation of plants. The closure of the passage of water to seeds is the most common cause of delay in seed germination. Cassia species suffer from the dormancy resulting from preventing water from entering the thick seed cover, preventing water and oxygen from reaching inside (Karthika et al., 2016). The hard casing and low germination rate are the main determinants of commercial cultivation of these species (Al-Menaie et al., 2009). Several treatments have been proposed to overcome the hardness of the casing and improve the rate of germination over a relatively short period.

$\mathrm{GA}_{3}$ is one of the most used to stimulate germination as well as stimulating seedling elongation (Hudson, 2005). Several studies have shown that the treatment of seeds with sulfuric acid resulted in a break in seed dormancy. Begum et al. (2013) noted that Cassia auriculata seeds were successfully seeded with $100 \mathrm{mg} \mathrm{L}^{-1}$ for 3 hrs which raised from 20 to $98 \%$ as the best seedlings. Sherif and Kalabi (2017) soaked the seeds of Pinus halepensis in $300 \mathrm{mg} \mathrm{L}^{-1}$ gibberellic acid which increased the proportion of germination and the height of seedlings.

This research was initiated in order to find out the effect of gibberellic acid on seed germination and growth performance of two species of Cassia.

\section{MATERIALS AND METHODS}

The experiment was conducted in the plastic-house of the Department of Horticulture and Landscape at the College of Agriculture and Forestry, University of Mosul during the period from 10/4/2018 to 31/1/2019.

Each seed was planted in a depth twice length in a plastic bowl $(8 \mathrm{~cm}$ height, $6 \mathrm{~cm}$ diameter) full with a medium consisting of perlite, peat moss, and sand with 1:1:1(v/v/v) ratio. The developing seedlings were then pecked out to plastic pots with a diameter of $15 \mathrm{~cm}$ and a height of $12 \mathrm{~cm}$ in the same agricultural medium and transplanted into the plastic-house after germination.

The study was carried out as $2 \times 3$ factorial experiments within randomized complete block design (RCBD). The first factor was two species of Cassia: Cassia surattenesis and Cassia siamea placed in the main plot, while the second factor was soaking seeds in gibberellic acid at three levels $\left(0,500\right.$ and $\left.1000 \mathrm{mg} \mathrm{L}^{-1}\right)$ for $48 \mathrm{hrs}$ placed in the subplot. The experiment consisted of 24 experimental units resulting from the interaction of the two factors with four replicates. The experimental unit contained 25 seeds. Germination percentage (\%) was calculated by counting the number of natural shootings at the end of the count, 19 days for the first species, 60 days for the second species for all replicates.

The average of the four replicates was calculated by applying the following formula adopted from the International Rules for Seed Testing (International Seed Testing Association, 1996).

$$
\underset{\text { percentage }}{\text { Germination }}=\frac{\begin{array}{c}
\text { Number of seeds } \\
\text { germinated }
\end{array}}{\begin{array}{c}
\text { Total number of seeds } \\
\text { sown }
\end{array}} \times 100
$$

The percentage of seedling survived (\%): which were able to resist seedling wilt disease, when transferred to the plastic-house covered with saran. It was calculated according to the following equation: 


$$
\begin{gathered}
\text { Survival } \\
\text { percentage }
\end{gathered}=\frac{\begin{array}{c}
\text { Number of seedlings } \\
\text { survived }
\end{array}}{\begin{array}{c}
\text { Total number of seeds } \\
\text { sown }
\end{array}} \times 100
$$

Also measured by the rate of seedling day $^{-1}$ : according to the equation cited by Heydecker (1968).

$\underset{\text { rate }}{\text { Germination }}=\frac{G_{1}}{T_{1}}+\ldots \ldots \frac{G_{2}}{T_{2}}+\frac{G_{n}}{T_{n}}$

$G_{1}, G_{2}, \ldots . ., G_{n}$ : represent germination calculated per day (n).

$\mathrm{T}_{1}, \mathrm{~T}_{2}, \ldots . ., \mathrm{T}_{\mathrm{n}}$ : time taken in days $(5,10,15$, 19 days for the first species) and (40, 45, 50, 55,60 days for the second species).

At the end of the experiment, the following parameters were measured: seedling height $(\mathrm{cm})$, leaf area $\left(\mathrm{cm}^{2}\right)$, fresh and dry biomass of seedling (g) and the force of the seedling (shoot vigor index "SVI") according to the equation: germination percentage $(\%) \times$ branch length $(\mathrm{cm})$.

The SAS program was used to analyze data and means of treatments were compared statistically by using Duncan's multiple test at $5 \%$.

\section{RESULTS AND DISCUSSION}

Data presented in Tables (1 and 2) show the effect of different gibberellic acid concentrations on germination and seedling growth parameters of two species of Cassia. Over all, C. surattensis was significant in germination percentage, survival percentage and germination rate when comparted to $C$. siamea. However, C. surattensis on the other hand was more significant in the attributes of the strength of the branch and the biomass of dry and fresh weights. As for the effect of gibberelic acid, when increasing the concentration of gibberelic acid, a significant upsurge in germination percentage, survival percentage and germination rate were obtained. Meanwhile, the higher concentration (1000 $\left.\mathrm{mg} \quad \mathrm{L}^{-1}\right)$ caused significant increases in seedling height, shoot vigor index, biomass for fresh and dry weights when comparted to the control.

Following the results of germination parameters, C. surattensis was observed significant in all parameters of germination compared to $C$. siamea, which ranged from 50 to $90 \%$. In many other studies (Rocas, 2004 and Acquah et al., 2015) germination ranged from $12.33-23.00 \%$ which may be due to the fact that the seeds used are stored for a long period of time or that the seeds may be stored in unsuitable conditions (Acquah et al., 2015), and that the superiority of species $C$. surattensis in the survival percentage and germination rate above $C$. siamea can be attributed to the high percentage of germination (Bashi and Alkhero, 2017). Also, the results showed that the increase in the concentration of gibberellic acid caused increases in the survival percentage and the rate of germination of $C$. surattensis and the high concentration only increased in the percentage of germination. While in $C$. siamea, both concentrations of gibberellic acid were appropriate to increase the percentage of plants survival. Results of germination agreed with both Begum et al. (2013) when Cassia auriculata seeds were soaked with gibberellic acid at a concentration of $100 \mathrm{mg} \mathrm{L}^{-1}$ for 3 hours and with Rout et al. (2017) when Cassia fistula seeds were soaked with gibberellic acid at a concentration of $760 \mathrm{mg} \mathrm{L}^{-1}$.

As for the results of the seedling characteristics, C. Surattensis was superior in all seedling traits except for the leaf area. Some important things can be discussed, although the growth period of $C$. siamea was relatively low compared with $C$. surattensis due to the delay of germination, but it's fast growing Feature gave the seedling height a similar rise boost. Another important issue is the superiority of $C$. siamea in the leaf area over $C$. surattensis. This can be due to the nature of leaves, which contain the largest number of leaflet pairs, which was positively reflected in the increase of leaf area, although there is no difference in the number 


\section{A.F. Al-Ma'athedi and Eman H. Mohammad}

Table 1. Influence of gibberellic acid concentration on germination parameters of two Cassia species.

\begin{tabular}{|c|c|c|c|c|}
\hline \multicolumn{2}{|c|}{ Treatments } & $\begin{array}{c}\text { Germination percentage } \\
(\%)\end{array}$ & $\begin{array}{c}\text { Survival percentage } \\
\text { (\%) }\end{array}$ & $\begin{array}{l}\text { Germination rate } \\
\left(\text { seedling day }{ }^{-1} \text { ) }\right.\end{array}$ \\
\hline \multicolumn{5}{|c|}{ Cassia species } \\
\hline \multicolumn{2}{|c|}{ C. surattensis } & $4.95 \mathrm{a}$ & 35.11 a & 50.33 а \\
\hline \multicolumn{2}{|c|}{ C. siamea } & $0.64 \mathrm{~b}$ & $19.00 \mathrm{a}$ & $26.44 \mathrm{~b}$ \\
\hline \multicolumn{5}{|c|}{ Gibberellic acid conc. (mg L-1) } \\
\hline \multicolumn{2}{|l|}{0} & $1.91 \mathrm{c}$ & $21.33 \mathrm{c}$ & 31.66 c \\
\hline \multicolumn{2}{|l|}{500} & $2.76 \mathrm{~b}$ & $28.16 \mathrm{~b}$ & $38.50 \mathrm{~b}$ \\
\hline \multirow{2}{*}{\multicolumn{2}{|c|}{1000}} & $3.72 \mathrm{a}$ & 31.66 a & $45.00 \mathrm{a}$ \\
\hline & & Cassia species $\times$ Gibb & llic acid conc. $\left(\mathrm{mg} \mathrm{L}^{-1}\right)$ & \\
\hline \multirow{4}{*}{$\begin{array}{l}\text { C. } \\
\text { surattensis }\end{array}$} & $\mathbf{0}$ & $3.40 \mathrm{c}$ & $30.00 \mathrm{c}$ & $43.66 \mathrm{~b}$ \\
\hline & 500 & $4.86 \mathrm{~b}$ & $35.00 \mathrm{~b}$ & $48.66 \mathrm{~b}$ \\
\hline & 1000 & $6.61 \mathrm{a}$ & 40.33 a & 58.66 a \\
\hline & 0 & $0.42 \mathrm{~d}$ & $12.66 \mathrm{e}$ & $19.66 \mathrm{~d}$ \\
\hline \multirow[t]{2}{*}{ C. siamea } & 500 & $0.67 \mathrm{~d}$ & $21.33 \mathrm{~d}$ & $28.33 \mathrm{c}$ \\
\hline & 1000 & $0.84 \mathrm{~d}$ & $23.00 \mathrm{~d}$ & $31.33 \mathrm{c}$ \\
\hline
\end{tabular}

Means within a column having the same letters are not significantly different according to Duncan's multiple range test.

Table 2. Influence of gibberellic acid concentration on seedling growth parameters of two Cassia species.

\begin{tabular}{|c|c|c|c|c|c|c|}
\hline \multicolumn{2}{|c|}{ Treatments } & $\begin{array}{l}\text { Seedling } \\
\text { height } \\
\text { (cm) }\end{array}$ & $\begin{array}{c}\text { Leaf area } \\
\left(\mathrm{cm}^{2}\right)\end{array}$ & $\begin{array}{l}\text { Shoot vigor } \\
\text { index }\end{array}$ & $\begin{array}{c}\text { Fresh weight } \\
\text { biomass (g) }\end{array}$ & $\begin{array}{l}\text { Dry weight } \\
\text { biomass (g) }\end{array}$ \\
\hline \multicolumn{7}{|c|}{ Cassia species } \\
\hline \multicolumn{2}{|c|}{ C. surattensis } & 24.73 a & $681 \mathrm{~b}$ & 849.56 a & $57.16 \mathrm{a}$ & $11.34 \mathrm{a}$ \\
\hline \multirow{2}{*}{\multicolumn{2}{|c|}{ C. siamea }} & 25.15 a & 1152 a & $424.29 \mathrm{~b}$ & $26.80 \mathrm{~b}$ & $4.85 \mathrm{~b}$ \\
\hline & & \multicolumn{5}{|c|}{ Gibberellic acid conc. $\left(\mathrm{mg} \mathrm{L}^{-1}\right)$} \\
\hline \multicolumn{2}{|l|}{0} & $24.00 \mathrm{~b}$ & 858 a & 504.97 c & 44.99 a & $8.72 \mathrm{a}$ \\
\hline \multirow{2}{*}{\multicolumn{2}{|c|}{$\begin{array}{l}500 \\
1000\end{array}$}} & $24.32 \mathrm{~b}$ & 860 a & $635.91 \mathrm{~b}$ & $49.00 \mathrm{a}$ & $8.74 \mathrm{a}$ \\
\hline & & 26.50 a & 1032 a & 769.90 a & $31.66 \mathrm{~b}$ & $6.83 \mathrm{~b}$ \\
\hline \multicolumn{2}{|l|}{1000} & Cassia & × Gibber & acid conc. (mg & & \\
\hline \multirow{4}{*}{$\begin{array}{l}\text { C. } \\
\text { surattensis }\end{array}$} & $\mathbf{0}$ & $24.47 \mathrm{~b}$ & 832 b-d & $722.35 \mathrm{~b}$ & 65.79 a & $8.72 \mathrm{a}$ \\
\hline & 500 & $24.96 \mathrm{~b}$ & $657 \mathrm{~d}$ & $854.70 a-b$ & 65.09 a & $8.74 \mathrm{a}$ \\
\hline & 1000 & $24.57 \mathrm{~b}$ & $553 \mathrm{~d}$ & $971.64 \mathrm{a}$ & $40.60 \mathrm{~b}$ & $6.83 \mathrm{~b}$ \\
\hline & 0 & $23.52 \mathrm{~b}$ & $885 \mathrm{~b}-\mathrm{d}$ & $287.58 \mathrm{~d}$ & $24.19 \mathrm{c}$ & $8.72 \mathrm{a}$ \\
\hline \multirow[t]{2}{*}{ C. siamea } & 500 & $23.69 \mathrm{~b}$ & $1062 \mathrm{~b}$ & $417.11 \mathrm{~d}$ & $33.51 \mathrm{~b}$ & $8.74 \mathrm{a}$ \\
\hline & 1000 & 28.25 a & 1511 a & $568.17 \mathrm{c}$ & $22.71 \mathrm{c}$ & $6.83 \mathrm{~b}$ \\
\hline
\end{tabular}

Means within a column having the same letters are not significantly different according to Duncan's multiple range test.

of leaves. The results also showed the positive role of gibberellic acid at a high concentration in the production of excellent seedlings of $C$. siamea, which resulted in an increase in seedling height and leaf area, while low concentration was better in improving the fresh weight biomass. The high concentration of gibberellic acid was excellent to increase shoot vigor index in $C$. surattensis. This result agreed with Venkatesh et al. (2000), who attributed the increase in the leaf area when the Pongamia pinnata seeds were socked in gibberellic acid. The increase in seedling height could be due to its role in the process of division and elongation of cells (Auskalniene and Auskalis, 1996). Differences between the two species under study in the traits of seedlings can be interpreted on the basis of genetic differences between species. Results herewith corresponded with what those 
happened by Bashi and Alkhero (2017) on Bauhinia.

\section{REFERENCES}

Acquah, S.B.; Oduro, K.A. and Darko-obiri, B. (2015). Silvicultural prescriptions for management of wood fuel species. CSIRForestry Research Institute of Ghana, 125.

Al-Menaie, H.S.; Al-Ragam, O.; Al-Shatti, A. and Mathew, M. (2009). Germination behavior of seed of four flowering trees of the genus Cassia under arid climatic conditions of Kuwait. European Journal of Scientific Research, 38(3):383-379.

Auskalniene, O. and Auskalis, A. (1996). Plant growth regulators in winter wheat under Lithuanian conditions. Lucrări Ştiinţifice, Seria Agronomie, 51:220-225.

Bashi, B.Z.A. and Alkhero, A.E.M. (2017). Effect of planting date, $\mathrm{GA}_{3}, \mathrm{KNO}_{3}$ on seed germination and plants growth of Bauhinia spp. Agriculture of the RAF, 45 (2):101-112.

Begum, A.J.; Vijayakumar, A. and Selvaraju, P. (2013). Standardization of seed dormancy breaking treatment in senna (Cassia auriculata). Academic Journals of Plant Breeding and Crop Science, 5(11): 220-223.

Hanelt, P.; Buttner, R. and Mansfeld, R. (2001). Mansfield's Encyclopedia of Agricultural and Horticultural Crops (except Ornamentals). Berlin, Germany: Springer, $3641 \mathrm{p}$.

Heydecker, W. (1968). Clarity in recording germination data. Nature, Lond., 210: 743-744.

Hudson, J.L. (2005). Gibberellic acid kits and supplies, gibberellic acid-3 information sheet. Available at http://www.jlhudsonseeds.net/Gibberellic Acid.htm.

International Seed Testing Association (1996). International Rules for Seed Testing. Seed Science and Technology, 24 (Supplement): 1-335.
Jonsson, K.; Fidjeland, L.; Maghembe, J.A. and Hogber, P. (1988). The vertical distribution of fine roots of five tree species and maize in Morogoro, Tanzania. Agro. Forestry Systems, 6(1): 63-69.

Karthika, C.; Rafi, K.M. and Manivannan, S. (2016). Effect of different pretreatments on vitro seed germination and seedling development of Senna alata Linn. International Journal Pharmaceutical Sciences and Research, 7(5):2157-2162.

Khan, M.R. (2013). Effect of heavy metals on seeds germination of some Cassia species. Weekly Science Research Journal, 1(13):1-6.

Kumar, U.S. (2015). Bioactivity determination of Cassia surattensis seed extract. Institute for Research in Molecular Medicine, 1-24.

Meena, R. and Sharma, C. (2014). Growth of Cassia siamea Lam. in semi-arid agro ecosystems. International Journal of Science and Research. pp: 95-97.

Parrotta, J.A. and Francis, J.K. (1990). Senna siamea Irwin \& Barneby. SO-ITF-SM33. Rio Piedras, Institute of Tropical Forestry, New Orleans, U.S., 7 p.

Rocas, A.N. (2004). Tropical tree seed manual-species descriptions, Senna siamea (Lam.) H.S. Irwin \& Bameby. https://rngr.net/publications/ttsm/species/ PDF.2004-03-16.2935

Rout, S.; Beura, S.; Khare, N.; Patra, S.S. and Nayak, S. (2017). Effect of seed pretreatment with different concentrations of gibberellic acid $\left(\mathrm{GA}_{3}\right)$ on seed germination and seedling growth of Cassia fistula L. Journal of Medicinal Plants Studies, 5 (6):135-138.

Sanyal, S. (2015). Evaluation of exomorphic characters of some India species of Cassia occurring in and around Kolkata, West Bengal with a nover view on cytotaxonomy. International Journal of Innovative Science, Engineering and Technology, 2(2):414-430. 


\section{A.F. Al-Ma'athedi and Eman H. Mohammad}

SAS Institute, (2001). The SAS system for Windows V 8.2 Cary, NC, USA.

Sastry, B.; Sreelatha, S.; Suresh, T.; Madhusudhana, B.K. and Rao, J. (2003). Phytochemical investigation of Cassia siamea Lam. National Seminar on Biodiversity Conservation and Commercial Exploitation of Medicinal Plants. Department of Botany. Osmania University, Hyderabad. pp: 39-40.

Sherif, S.G. and Al-Kharabi, J.K.J. (2017). Effect of concentrations, periods of soaking in gibberellic acid solution and shading percentage on germination and growth Aleppo pine seedlings (Pinus halepensis Mill.) in Kerbala Governorate.
Holy Karbala Scientific Journal, 15(2):16-26.

Venkatesh, A.; Vanangamudi, M.; Vanangamudi, K.; Parthiban, K.; Ravichandran, V. and Vinaya-Rai, R.C. (2000). Effect of growth stimulants on seed germination and morphysiological attributes in pungam (Pongamia pinnata). Journal of Tropical Forest Science, 12(4): 643-649.

Viegas Jr., C.; Vanderlan, S.B.; Magsa, F.; Eliezer, B.; Maria, M.C.; Daniela, T. and Marcos, N.E. (2004). Further bioactive piperidine alkaloids from the flowers and green fruits of Cassia spectabilis. Journal of Natural Products, 67(5):908-910.

\section{تأثير حامض الجبريليك على النسبة المئوية لانبات بذور نوعين من الكاسيا ومظاهر نموها}

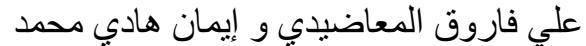

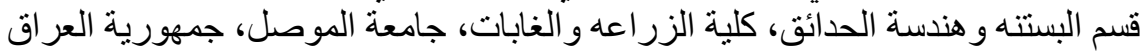

أجريت التجربة في البيت البلاستيكي التابع لقسم البستنة وهندسة الحدائق في كلية الزراعة و الغابات، جامعة

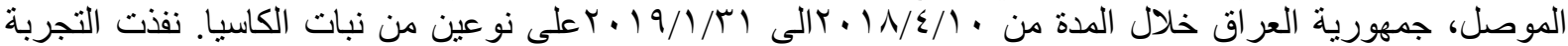

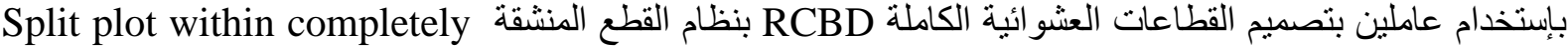
randomized block design

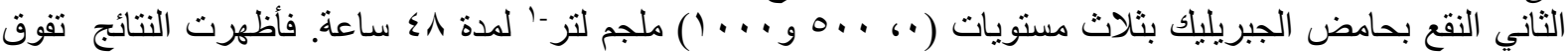

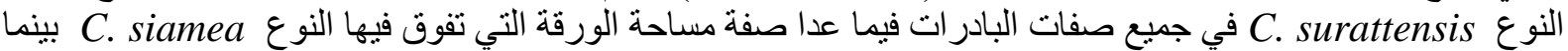
كان للجبريلين دور مهم في تحسين صفات البادرات عند استخدامه بكلا تركيزيه ولكاد النوعين. واستخدام التركيز العالي

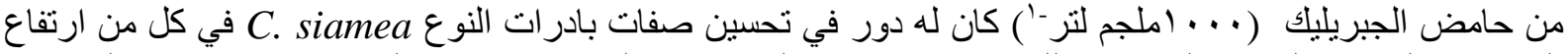

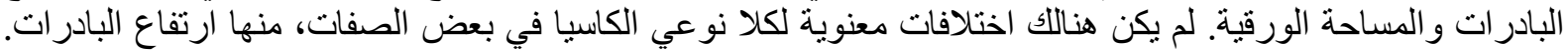

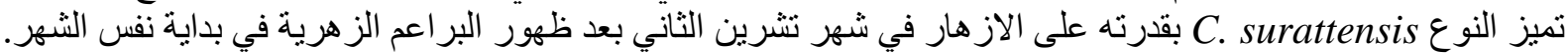

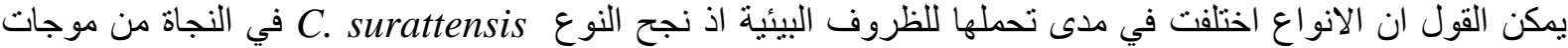
البرد على العكس منه النوع C. siamea الذي لم يتمكن من النجاة تحت نفس الظروف الحسئلة في شهر كانون الثاني. 